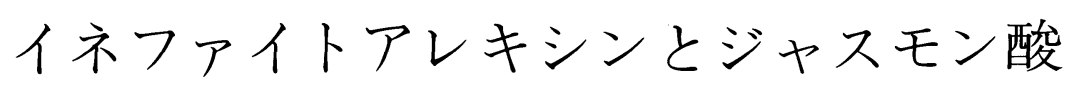

\author{
田母神 繁 \\ 秋田県立大学 生物資源科学部 \\ (平成 12 年 11 月 20 日受理)
}

\title{
Phytoalexins and Jasmonic Acid in Rice Plants
}

\author{
Shigeru TAMOGAMI \\ Faculty of Bioresource Sciences, Akita Prefectural University, 241-7, Kaidobatanishi, Shimoshinjyo-nakano, \\ Akita 010-0195, Japan
}

Key words: ジャスモン酸 (jasmonic acid), ファイトアレキシン (phytoalexins), イネ (rice plants).

\section{は じめに}

ジャスモン酸 (1, 図 1) とそのメチルエステルは, 植物 に対しきわめて興味深い活性を示寸天然生理活性物質であ ク，その生理作用について様々な方面から研究がなされて いる.ここでは, 広範囲な生理作用の中から, ジャスモン 酸がファイトアレキシンと呼ばれる抗菌活性を示す植物 2 次代謝産物の蓄積を促進させる活性についての知見を紹介 する.

植物はストレスや病害に対する自己防御反応の一つとし てファイトアレキシンと呼ばれる低分子量の 2 次代謝産物 を生産することが知られている.ファイトアレキシンは植 物病原菌に感染した部位から単離されたのが研究の発端で あるが, それ以外のエリシターと呼ばれる塩化銅や多糖類 などの化合物，あるいは紫外線照射ストレスによってもそ の生産が促進されて蓄積されることが知られている1). 茨 城大学の児玉らはイネ葉からジテルペノイドやフラボノイ ドに属する数多くのファイトアレキシンを単離・構造決定 し ${ }^{2)}$ ささらにファイトアレキシンの蓄積機構について研究

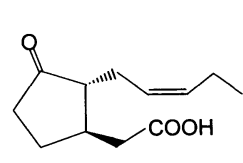

1

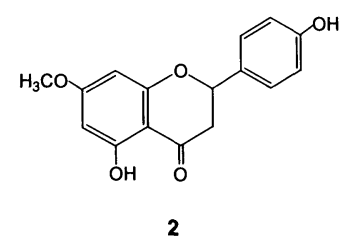

図 1 ジャスモン酸（1）とサクラネチン (2) の化学構造

を進めた。 その過程で, イネ葉の病原菌感染時において脂 肪酸やその過酸化物の生成がファイトアレキシンの蓄積に 関与することが示唆され, 次いで, 脂肪酸過酸化物のより 下流に位置する代謝産物であるジャスモン酸が高いエリシ ター活性を有することを見いだした ${ }^{3)}$. 以下, 茨城大学・児 玉研究室で進められた，イネファイトアレキシン蓄積にお けるジャスモン酸の役割についての研究結果を紹介する.

\section{ジャスモン酸のエリシター活性}

イネファイトアレキシンの一つであるサクラネチン $(\mathbf{2}$, 図 1) は, イネ健全葉にはほとんど存在しないが, ジャスモ ン酸を処理すると(数 $\mu$ モルから数 $\mathrm{m}$ モル濃度のジャスモ ン酸水溶液の液滴をイネ葉上に静置する), 処理部あたり数 百ナノグラムにも達するサクラネチンの蓄積が引き起こさ れる(図2[I])．ジテルペノイドのファイトアレキシンであ るモミラクトン A の蓄積も同様に促進されるが,ここでは サクラネチンの蓄積に絞って述べる.フェニルアラニン以 降の, サクラネチンの推定生合成経路を図 3 に示した。サ クラネチン生合成の鍵ステップであると思われるフェニル アラニンから桂皮酸への変換や, ナリンゲニンの 7 位水酸 基のメチル化反応を触媒する酵素活性を調べた結果, 前者 を触媒するフェニルアラニンアンモニアリアーゼ (PAL)， 後者を触媒するナリンゲニン 7-O-メチルトランスフェ ラーゼ (NOMT) の酵素活性が, ジャスモン酸処理によっ て著しく高まっていることが明らかにされた ${ }^{4)}$.このイネ 葉におけるサクラネチンの蓄積は，その分解が阻害される 

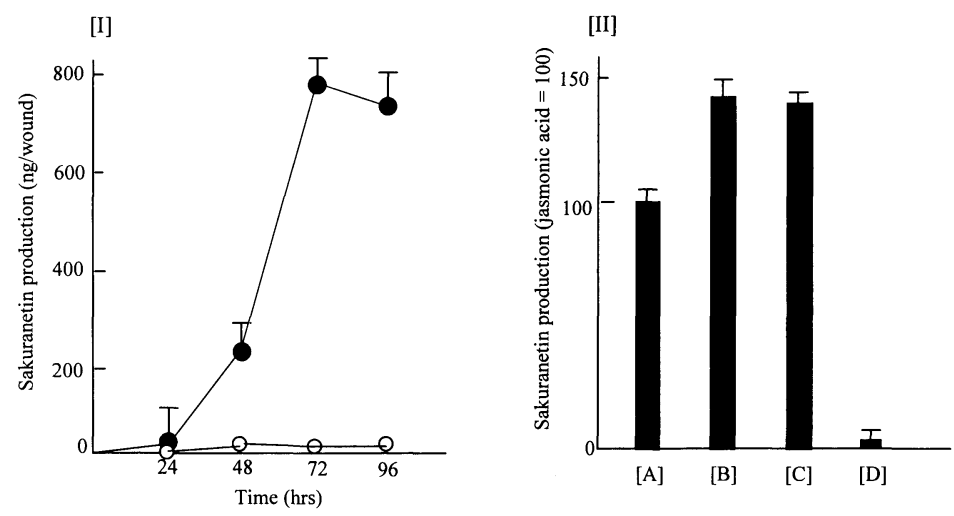

図 $2[\mathrm{I}]$ : ジャスモン酸 $(0.5 \mathrm{~mm})$ を処理したイネ葉でのサクラネチン蓄積量の経時変化(・：ジャスモン酸処理, ○：水処理). [II]：ジャスモン酸とアミノ酸結合型ジャスモン酸とのエリシター活性の相対比較 (72 時間後のイネ葉中のサクラネチン量を比 較し, ジャスモン酸＝100 とした). [A]：ジャスモン酸 $(0.25 \mathrm{~mm}),[\mathrm{B}]$ ：フェニルアラニン結合型ジャスモン酸 $(0.25 \mathrm{~mm})$, $[\mathrm{C}]$ ：ロイシン結合型ジャスモン酸 $(0.25 \mathrm{~mm}),[\mathrm{D}]$ : コントロール (水).

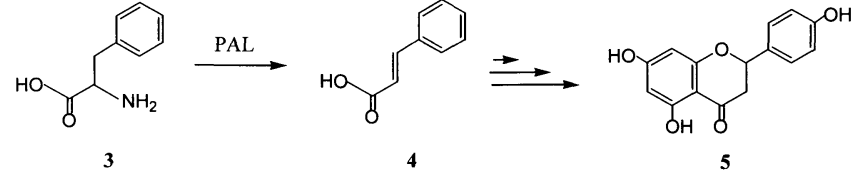<smiles>COc1cc(O)c2c(c1)OC(c1ccc(O)cc1)CC2=O</smiles>

図 3 フェニルアラニン以降のサクラネチン生合成推定 経路

3: フェニルアラニン, 4 : 桂皮酸, 5 : ナリンゲニン, $2:$ サ クラネチン, PAL：フェニルアラリンアンモニアリアーゼ, NOMT：ナリンゲニン-7-O-メチルトランスフェラーゼ.

といった単純な理由ではなく, サクラネチンの生合成が活 性化されていることが示された，前者のPALについては， イネ以外の植物においてもジャスモン酸による活性化が報 告されている。一方，ナリンゲニンはイネいもち病菌に対 してほとんど抗菌活性を示さず，メチル化されたサクラネ チンとなってはじめて高い抗菌活性を示す。サクラネチン 生合成の要である十リンゲニンがジャスモン酸によって活 性化されることは興味深い.

ジャスモン酸はリノレン酸から生合成され, 12-oxo-PDA と呼ばれる中間体を経ることがマメ科植物において明らか にされている5).また，ジャスモン酸の下流に位置するとさ れる代謝物として糖やアミノ酸との結合型ジャスモン酸の 存在も知られている.リノレン酸はエリシター活性を示さ ないが，この中間体 12-oxo-PDA はサクラネチンの蓄積を 引き起こす活性を示した。さらに興味あることに，アミ， 酸結合型ジャスモン酸はジャスモン酸よりも高い活性を示 した $(\text { 図 } 2[\mathrm{II}])^{4)}$.アミノ酸結合型ジャスモン酸の重要性は

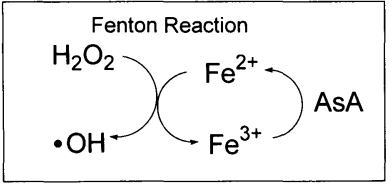

図4 フェントン反応とアスコルビン酸（AsA）の作用

マメ科植物における天敵誘引物質の生合成においても示唆 されている ${ }^{6)}$.一方, 他に数種のジャスモン酸アナログにつ いてのエリシター活性が調べられたが，どれもジャスモン 酸よりも弱いエリシター活性を示すに過ぎなかった4).

\section{ジャスモン酸のエリシター活性に対する 種々の化合物の効果}

このジャスモン酸よるサクラネチン蓄積を指標とした工 リシター活性について，どのような化合物が影響を与える かを調べた結果, 植物ホルモンであるカイネチンやゼアチ ンなどのサイトカイニンがジャスモン酸の活性を完全に阻 害することが見いだされた. また, 低濃度のアスコルビン 酸がジャスモン酸のエリシター活性を抑制し, 逆に, 高濃 度では著しく促進することが見いだされた7)。一般に，アス コルビン酸はラジカルのスカベンジャーとして機能するこ とが知られているが，アスコルビン酸が過㮃に存在すると 逆にハイドロキシラジカルなどの生成を促進させることが 知られている，このハイドロキシラジカルの生成は，還元 型の鉄イオンが介在するフェントン反応 (図 4)によるもの であり，アスコルビン酸は還元型の鉄イオンを再生させる ことで，このフェントン反応を促進させうると考えられ る ${ }^{8)}$.また, グルタチオンやトコフェロールなどの過酸化を 阻害する物質もアスコルビン酸と同様にジャスモン酸の活 性を促進する活性を示した9). 鉄イオンなどの金属イオン のキレート化合物であるエチレンジアミン四酢酸 (EDTA) によって，アスコルビン酸の効果やジャスモン酸のエリシ 
夕一活性自体が阻害されたことから，ジャスモン酸によっ て処理されたイネ葉がサクラネチンを蓄積させる過程に は，活性ラジカルやフェントン反応に関与する鉄イオンな どの金属イオンが介在する可能性も示唆された ${ }^{9}$. ジャス モン酸処理によってペルオキシダーゼ活性が増加すること は数種の植物において示されており ${ }^{10)}$ ，イネ葉におけるサ クラネチンの蓄積においても，ペルオキシダーゼによる生 成物，あるいはペルオキシダーゼが引き起こす作用がその 活性に関与しているのかも知れない.

サイトカイニンがジャスモン酸のエリシター活性を阻害 する活性は強く, $0.25 \mathrm{~mm}$ 濃度のジャスモン酸による活性 は，数 $\mu \mathrm{m}$ のカイネチンで完全に阻害された ${ }^{7)}$. ジャスモン

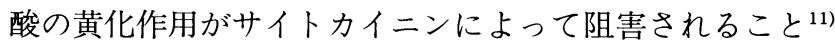
は以前から知られてたが，ジャスモン酸のエリシター活性 もまたサイトカイニンによって著しく阻害されることは興 味深い。一般に，植物体に外部から化合物を与えてその効 果を評価するときには，内生の植物ホルモン量や，その他 の細胞内物質の効果を考虑すべきなのは当然であり，ジャ スモン酸もまた例外ではなく，イネ葉に外部からジャスモ ン酸を処理してその活性を評価する場合にも内生サイトカ イニンの効果を考慮する必要があると思われる。なお,ジャ スモン酸と同様な黄化作用を有するアブシジン酸はエリシ ター活性をまったく示さず，黄化作用とエリシタ一活性と は結びついていないと考えられる。ジャスモン酸のエリシ タ一活性に関与する化合物と関与の推定機構について，図 5 にまとめた。このサイトカイニンの作用機構の解析につ いては今後の興味ある課題の一つであろう。

以上のように，ジャスモン酸によるイネ葉でのサクラネ チンの蓄積について紹介してきた。一方，モミラクトン A などイネ葉が生産する他のファイトアレキシンもジャスモ ン酸処理によって多量に蓄積するが，その蓄積はサイトカ イニンによって阻害されることはなく，サクラネチンの蓄 積メカニズムとは異なる点が多い，それらの結果はここで は省いた。

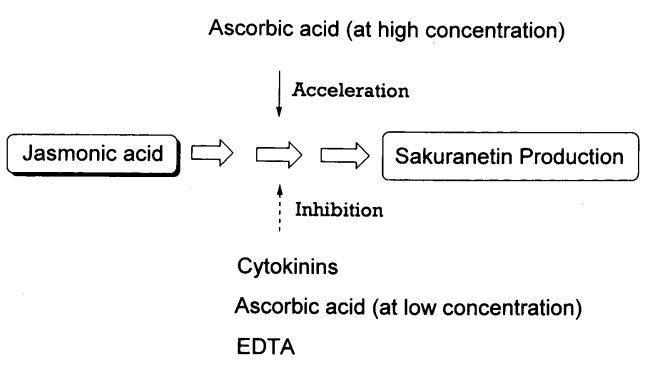

図 5 ジャスモン酸のエリシター活性（イネ葉におけるサ クラネチンの蓄積）に影響をあたえる化合物

\section{細胞内シグナル物質としてのジャスモン酸}

イネ葉に外部からジャスモン酸を与えた場合のエリシ 夕一活性については図 5 のような結果が得られたが，植物 の自己防御機構の一つとしてイネ葉が病原菌の感染に対し てサクラネチンを蓄積する過程において，内生のジャスモ ン酸がどのように関与しているかについては別な研究を進 める必要がある、イネ葉中でのジャスモン酸，およびアミ ノ酸結合型ジャスモン酸の含有量を LC-MS/MS 分析によ り調べたところ，傷害ストレスに呼応する鋭敏な増加と減 少が観察された ${ }^{12)}$. トマト葉では, 病害感染や傷害ストレス とそれに対応するタンパク質の生成において，ジャスモン 酸を細胞内のシグナル物質として位置づけるモデルが考之 られているが13)，イネ葉に扔ける内生ジャスモン酸の役割 についてもそれがそのままあてはまるかどうかは，まだ不 確定であろう。少なくとも，イネ葉においてはサイトカイ ニンの関与についての研究が必要であるように思う。また， イネ葉にはロイシンやバリン結合型のアミノ酸が存在し, かつ，これらの化合物も高いエリシター活性を示すことか ら，ジャスモン酸だけではなく，その代謝産物の働きも無 視できないように思える.

ジャスモン酸は動物におけるアラキドン酸カスケードに おけるプロスタグランジノイドとしばしば比較される。し かし，リノレン酸代謝産物においては，ジャスモン酸以外 の類縁化合物の存在や生理機能については未知の部分が圧 倒的に多く，リノレン酸カスケードが存在するとは言えな い.イネ葉におけるジャスモン酸の生合成経路がマメ科植 物で明らかにされている経路と同様であるのか，あるいは 大きく異なるのかという点も不確定であり，大いに研究の 余地があると思われる。

\section{ジャスモン酸類似化合物のエリシター活性}

先に述べたように，アミノ酸が結合したジャスモン酸は 高い活性を示すが，ジャスモン酸の側鎖の二重結合に水素 を付加させたジヒドロジャスモン酸や，カルボニル基を還 元した化合物では活性が大きく低下した，一方，微生物毒 素として単離されたコロナチンは化学構造がジャスモン酸 に類似しているだけではなく，その生理作用もジャスモン 酸と共通することが知られている。イネ葉に扔けるエリシ 夕一活性を調べたところ，やはり，ジャスモン酸と同様の 高い活性を示し，興味あることに，コロナチンによるサク ラネチンの蓄積はカイネチンによって阻害され, 高濃度の アスコルビン酸によって著しく促進された ${ }^{14)}$ 。このジャス モン酸と同じ性向は，コロナチンがジャスモン酸と同じ機 構で作用することを示唆している．いかにコロナチンの化 学構造がジャスモン酸やアミノ酸結合型ジャスモン酸に類 似しているとはいえ，植物毒素が植物体内に存在する植物 
ホルモン様物質と同じ機構で作用することは興味深い.

\section{おわりに}

ジャスモン酸の生理活性の中から，イネのファイトアレ キシン蓄積を引き起こすエリシター活性に絞って研究結果 を紹介した。これらの研究結果は筆者が茨城大学児玉研究 室にて行ったものの一部である．改めて児玉治教授に感謝 するとともに，共同研究者の方々にもお礼申し上げる。こ こ数年, ジャスモン酸の生理機能に関する研究は盛んに行 われている. その基礎的な生理作用についての研究から， 細胞内シグナル物質としての役割, さらに特定の 2 次代謝 産物やタンパク質の誘導, あるいはジャスモン酸の結合蛋 白の単離についても研究されている。冒頭にも述べたよう にジャスモン酸の生理作用は多岐に渡っている。他の研究 領域における進捗については他の文献等にあたっていただ きたい15).

\section{引用 文 献}

1) J. W. Manfield: "Phytoalexin," ed. by J. A. Bailey \& J. W. Manfield, John and Wiley and Sons, New York, pp. 253288, 1982

2) O. Kodama, J. Miyakawa, T. Akatsuka \& S. Kiyosawa: Phytochemistry 31, 3807 (1992) and references cited therein

3) R. Rakwal, S. Tamogami \& O. Kodama: Biosci. Biotechnol. Biochem. 60, 1046 (1996)

4) S. Tamogami, R. Randeep \& O. Kodama: FEBS Lett. 401, 239. (1997)

5) M. Hamberg \& H. W. Gardner: Biochim. Biophys. Acta
1165, 1 (1992)

6) T. Kurum, K. Bandemer \& W. Boland: FEBS Lett. 377, 523 (1995)

7) S. Tamogami, R. Randeep \& O. Kodama: FEBS Lett. 412 , 61 (1997)

8) B. Halliwell, J. M. C. Gutterridge: フリーラジカルと生体, 松尾光芳, 嵯峨井勝, 吉川敏一訳, 学会出版センター, ' 1988

9) S. Tamogami, Ph. D. Thesis, The United Graduate School Tokyo University of Agriculture and Technology, Tokyo, Japan, 1998

10) T. Kato, Y. Shirano, H. Iwamoto \& D. Shibata: Plant Cell Physiol. 34, 1063 (1993)

11) J. Ueda \& J. Kato: Plant Physiol. 66, 246 (1980)

12) S. Tamogami \& O. Kodama: J. Chromatogr. A 822, 310 (1998)

13) E. E. Farmer \& C. A. Ryan: Plant Cell 4, 129 (1992)

14) S. Tamogami \& O. Kodama: Phytochemistry 54, 689 (2000)

15）高橋信孝，増田芳雄編：植物ホルモン・ハンドブック，培 風館, 1994 